\title{
Caregiver burden and coping strategies in schizophrenia: a hospital based study
}

\author{
Mishra SK ${ }^{1}$, Pandey AK ${ }^{2}$, Adhikari BR ${ }^{3}$, Nepal S $^{1}$ \\ 1.Assistant Professor, Department of Psychiatry, BPKIHS, Dharan, Nepal 2. Professor, Department of \\ Psychiatry, BPS Government College for Women, Sonepat, Haryana 3.Professor, Department of \\ Psychiatry, BPKIHS, Dharan Nepal
}

E-mail *Corresponding author: sanjeev10317@gmail.com

\begin{abstract}
Introduction: Schizophrenia is a severe mental illness which not only affects the patients but also causes significant distress to the caregivers, who use various strategies to minimize their distress. It is important to know about their suffering in order to include them in the treatment program.

Objective: To assess the severity of burden and coping strategies among the caregivers

Method: 36 admitted cases of patients and their caregivers were enrolled. Patients were assessed using PANSS while caregivers were assessed using BAS and COPE Inventory.

Result: $47.2 \%$ caregivers reported suffering from severe burden. The most severely affected areas were physical and mental health, taking responsibility, caregiver's routine and patient's behavior. Caregivers used both problem oriented and emotion oriented strategy to minimize the distress. The choice of coping strategy and severity of burden was not influenced by the patient's symptoms.

Conclusion: Caregivers of patients with schizophrenia suffered from significant burden and require additional care to help them alleviate their problems.
\end{abstract}

Keywords: Schizophrenia, Burden, Coping

\section{INTRODUCTION}

Schizophrenia is a severe mental disorder affecting 21 million people worldwide. It is characterized by distortions in thinking, perceptions, emotions, language, sense of self and behaviour. ${ }^{1}$ The resulting disability can have a considerable impact on the caregivers' daily lives, physical health and emotional well being. ${ }^{2}$

The term burden has been described as "the consequences for those in close contact with severely ill psychiatric patients". ${ }^{3}$ It has been classified into subjective and objective dimensions. Subjective burden refers to the psychological consequences of the individuals' illness on the family such as distress. Objective burden refers to the disruption in family or household and is usually observable such as household routines, relationships. ${ }^{4}$ However, some authors consider the term burden as derogatory and a more appropriate term is considered to be "caregiving". 5

The impact of schizophrenia on their caregivers has been a focus of considerable interest and a number of studies have shown that caregivers regularly suffer from various problems such as disruption of routines, relation problems, financial loss and emotional distress. ${ }^{6-11}$ In response to these problems, caregivers employ a variety of coping strategies which include approach strategies such as seeking support and education, positive reframing and problem solving as well as avoidant strategies such as denial and disengagement. ${ }^{12}$

Some studies have studied burden and coping in relation to patients' symptoms. While some found that burden and coping are influenced by 
positive symptoms ${ }^{13,14}$ others have concluded that negative symptoms are more helpful predictors of burden and coping strategies.15,16 Still others did not find any difference between the two domains of symptoms. ${ }^{4,17}$

In a country like Nepal, caregivers have to deal with the major brunt of patients' illness and this not only affects the caregivers' physical and mental health but also has adverse consequences for patients whose needs are frequently unmet due to decreased functionality of the caregivers. ${ }^{18}$ As stated by Rosenfarb et al (2006) cultural factors play an important role in determining the degree to which patients are experienced as burdensome. ${ }^{19}$ Hence this study was undertaken to assess the severity of burden and coping strategies among the caregivers and it's relation to patients' symptoms in context of Nepal.

\section{MATERIAL AND METHOD}

This is a descriptive and cross sectional study conducted among caregivers of patients with schizophrenia admitted in the psychiatry ward of BPKIHS. Patients and caregivers of all the patients admitted during a period of one year (January 2013 to December 2013) ( $\mathrm{N=36}$ ) were enrolled after obtaining informed consent. A semi-structured pro-forma was used to obtain information about the socio-demographic characters of the patients and caregivers. Patients were assessed using the Positive And Negative Syndrome Scale (PANSS) while the caregivers were assessed using the Burden Assessment Schedule (BAS) and the COPE Inventory. BAS and COPE Inventory were in English language and therefore, translation and back translation was done to obtain a Nepali language scale.

PANSS was developed by Kay et al in 1987 for the assessment of positive and negative symptoms in schizophrenia. It consists of 30 items in three subscales, positive symptoms, negative symptoms and general psychopathology. Each item is rated on a seven point scale which represents increasing levels of severity. The alpha coefficient for the three subscales are $0.73,0.83$ and 0.79 respectively. The PANSS score is summation of ratings across items, so the potential ranges are 7-49 for the positive and negative scales, 16-112 for the general psychopathology scale and -42 to +42 for the composite scale. ${ }^{20}$

BAS was developed by Thara et al (1998). This is a 40 item scale measuring seven different areas of burden. Each item is rated on a 3 point scale. Internal consistency for the full scale as measured by the alpha coefficient is 0.81 . Criterion validity was established by comparing the instrument with the family burden schedule (Pai and Kapur,1981). Correlations for most of the items was found to be good and ranged between 0.71-0.82.21

The COPE Inventory was developed by Carver et al (1989). It consists of 14 scales with each scale containing 4 items except for 1 (53 total). Each item is rated on a 1-4 scale so the total score for each item is $4-16.5$ of the scales measure problem based strategies. 5 others measure emotion based strategies while the rest measure coping responses that arguably are less useful. ${ }^{22}$

The collected data was entered in MicrosoftExcel 2007 and converted into SPSS 16.0 for statistical analysis. Descriptive statistics were analysed using mean, standard deviation, number and percentage while for inferential statistics chi square and pearson correlation was used.

\section{RESULT}

The mean age of patients was found to be $31.2 \pm$ 7.43 years while that of the caregivers was $42.8 \pm$ 14.8 years. $29(80.6 \%)$ patients were male while $7(19.4 \%)$ were female. Majority of the patients were Hindu, educated upto SLC, unemployed and unmarried. Similarly, $52.8 \%$ of the caregivers were male and the majority of caregivers were illiterate, married and farmer. $11(30.6 \%)$ of the caregivers were siblings of the patients while $8(22.2 \%)$ and $7(19.4 \%)$ were fathers and mothers respectively. (Table 1)

The assessment of patients using PANSS showed that the mean total score was $90 \pm$ 14.3SD. The mean score was highest for the general psychopathology subscale followed by negative subscale with the positive subscale having the lowest mean score (Table 2).

The mean burden score at the time of admission was 81.3 with a standard deviation of 15.9. The total burden score ranged from as less as 51 to as high as 106. 19(52.8\%) caregivers reported 
Table no. 1: Socio-demographic Profile Of $\underline{\text { Patients and Care-Givers }}$

\begin{tabular}{|c|c|c|c|}
\hline \multicolumn{2}{|c|}{ Variable } & Patients & Caregivers \\
\hline \multicolumn{2}{|c|}{ Mean Age \pm SD (years) } & $31.2 \pm$ & $42.8 \pm 14.8$ \\
\hline \multirow{5}{*}{$\begin{array}{c}\text { Age } \\
\text { distribution } \\
\text { No. }(\%)\end{array}$} & $18-30$ & $24(66.7)$ & 11(30.6) \\
\hline & $31-40$ & $8(22.2)$ & $7(19.4)$ \\
\hline & $41-50$ & $3(8.3)$ & $7(19.4)$ \\
\hline & $51-60$ & $1(2.8)$ & $6(16.7)$ \\
\hline & Above 60 & $0(0)$ & $5(13.9)$ \\
\hline \multicolumn{2}{|c|}{ Total } & $36(100.0)$ & $36(100.0)$ \\
\hline \multirow{2}{*}{$\begin{array}{l}\text { Gender } \\
\text { No. }(\%)\end{array}$} & Male & $29(80.6)$ & $19(52.8)$ \\
\hline & Female & $7(19.4)$ & $17(47.2)$ \\
\hline \multicolumn{2}{|c|}{ Total } & $36(100.0)$ & $36(100.0)$ \\
\hline \multirow{4}{*}{$\begin{array}{l}\text { Religion } \\
\text { No. (\%) }\end{array}$} & Hindu & $30(80.3)$ & $30(80.3)$ \\
\hline & Buddhist & $1(2.8)$ & $1(2.8)$ \\
\hline & Christian & $1(2.8)$ & $1(2.8)$ \\
\hline & Others (Kirat) & $4(11.1)$ & $4(11.1)$ \\
\hline Total & & $36(100.0)$ & $36(100.0)$ \\
\hline \multirow{6}{*}{$\begin{array}{l}\text { Education } \\
\text { No. }(\%)\end{array}$} & Illiterate & $0(0)$ & $12(33.3)$ \\
\hline & Primary & $4(11.1)$ & $3(8.3)$ \\
\hline & Middle & $5(13.9)$ & $6(16.7)$ \\
\hline & SLC & $14(38.9)$ & $513.9)$ \\
\hline & Intermediate & $9(25.0)$ & $4(11.1)$ \\
\hline & Graduate & $4(11.1)$ & $6(16.7)$ \\
\hline \multicolumn{2}{|c|}{ Total } & $36(100.0)$ & $36(100.0)$ \\
\hline \multirow{8}{*}{$\begin{array}{c}\text { Occupation } \\
\text { No. }(\%)\end{array}$} & Business & $2(5.6)$ & $2(5.6)$ \\
\hline & Farmer & $4(11.1)$ & $13(36.1)$ \\
\hline & Labourer & $7(19.4)$ & $4(11.1)$ \\
\hline & Service & $3(8.3)$ & $5(13.9)$ \\
\hline & Housewife & $1(2.8)$ & $7(19.4)$ \\
\hline & Student & $5(13.1)$ & $2(5.6)$ \\
\hline & Unemployed & $13(36.1)$ & $3(8.3)$ \\
\hline & Others & $1(2.8)$ & $0(0)$ \\
\hline \multicolumn{2}{|c|}{ Total } & $36(100.0)$ & $36(100.0)$ \\
\hline \multirow{3}{*}{$\begin{array}{c}\text { Marital } \\
\text { status } \\
\text { No. }(\%)\end{array}$} & Bachelor & $18(50.0)$ & $7(19.4)$ \\
\hline & Married & $16(44.4)$ & $29(80.6)$ \\
\hline & Single & $2(5.6)$ & $0(0)$ \\
\hline \multicolumn{2}{|c|}{ Total } & $36(100.0)$ & $36(100.0)$ \\
\hline \multirow{5}{*}{$\begin{array}{c}\text { Relation to } \\
\text { patient } \\
\text { No. }(\%)\end{array}$} & Father & - & $8(22.2)$ \\
\hline & Mother & - & $7(19.4)$ \\
\hline & Spouse & - & $9(25.0)$ \\
\hline & Sibling & - & $11(30.6)$ \\
\hline & Other (Uncle) & - & $1(2.8)$ \\
\hline \multicolumn{2}{|c|}{ Total } & - & $36(100.0)$ \\
\hline
\end{tabular}

Table no. 2: Showing PANSS Score during Admission

\begin{tabular}{|c|c|c|}
\hline PANSS & Mean & SD \\
\hline Total & 90.1 & 14.3 \\
\hline Positive subscale & 25.0 & 11.0 \\
\hline Negative subscale & 26.4 & 11.2 \\
\hline General psychopathology & 38.5 & 7.7 \\
\hline
\end{tabular}

Table no. 3: Distribution of caregiver sample in various domains of burden

\begin{tabular}{|c|c|c|c|c|}
\hline BAS & $\begin{array}{c}\text { Assessment } \\
\text { of severity }\end{array}$ & Number & Percentage & $\begin{array}{c}\mathbf{P} \\
\text { value }\end{array}$ \\
\hline \multirow{3}{*}{$\begin{array}{l}\text { Total } \\
\text { burden }\end{array}$} & None & 0 & 0 & \multirow[t]{3}{*}{0.74} \\
\hline & $\begin{array}{c}\text { To some } \\
\text { extent }\end{array}$ & 19 & 52.8 & \\
\hline & Very much & 17 & 47.2 & \\
\hline \multirow{3}{*}{$\begin{array}{l}\text { Spouse } \\
\text { related }\end{array}$} & None & 0 & 0 & \multirow[t]{3}{*}{0.73} \\
\hline & $\begin{array}{c}\text { To some } \\
\text { extent }\end{array}$ & 4 & 44.4 & \\
\hline & Very much & 5 & 55.6 & \\
\hline \multirow{3}{*}{$\begin{array}{c}\text { Physical and } \\
\text { mental } \\
\text { health }\end{array}$} & None & 0 & 0 & \multirow[t]{3}{*}{0.02} \\
\hline & $\begin{array}{c}\text { To some } \\
\text { extent }\end{array}$ & 11 & 30.6 & \\
\hline & Very much & 25 & 69.4 & \\
\hline \multirow{3}{*}{$\begin{array}{l}\text { External } \\
\text { support }\end{array}$} & None & 0 & 0 & \multirow[t]{3}{*}{$<0.001$} \\
\hline & $\begin{array}{c}\begin{array}{c}\text { To some } \\
\text { extent }\end{array} \\
\end{array}$ & 30 & 83.3 & \\
\hline & Very much & 6 & 16.7 & \\
\hline \multirow{3}{*}{$\begin{array}{c}\text { Caregiver's } \\
\text { routine }\end{array}$} & None & 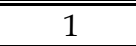 & 2.8 & \multirow[t]{3}{*}{$<0.001$} \\
\hline & $\begin{array}{c}\text { To some } \\
\text { extent }\end{array}$ & 12 & 33.3 & \\
\hline & Very much & 23 & 63.9 & \\
\hline \multirow{3}{*}{$\begin{array}{c}\text { Support of } \\
\text { patient }\end{array}$} & None & 1 & 2.8 & \multirow[t]{3}{*}{0.001} \\
\hline & $\begin{array}{c}\text { To some } \\
\text { extent }\end{array}$ & 17 & 47.2 & \\
\hline & Very much & 18 & 50.0 & \\
\hline \multirow{3}{*}{$\begin{array}{l}\text { Taking } \\
\text { responsibility }\end{array}$} & None & 0 & 0 & \multirow[t]{3}{*}{0.02} \\
\hline & $\begin{array}{c}\text { To some } \\
\text { extent }\end{array}$ & 11 & 30.6 & \\
\hline & Very much & 25 & 69.4 & \\
\hline \multirow{3}{*}{$\begin{array}{l}\text { Other } \\
\text { relations }\end{array}$} & None & 3 & 8.3 & \multirow[t]{3}{*}{0.004} \\
\hline & $\begin{array}{c}\text { To some } \\
\text { extent }\end{array}$ & 14 & 38.9 & \\
\hline & Very much & 19 & 52.8 & \\
\hline \multirow{3}{*}{$\begin{array}{l}\text { Patient's } \\
\text { behaviour }\end{array}$} & None & 0 & 0 & \multirow[t]{3}{*}{0.04} \\
\hline & $\begin{array}{c}\text { To some } \\
\text { extent }\end{array}$ & 12 & 33.3 & \\
\hline & Very much & 24 & 66.7 & \\
\hline \multirow{3}{*}{$\begin{array}{c}\text { Caregiver's } \\
\text { strategy }\end{array}$} & None & 0 & 0 & \multirow[t]{3}{*}{0.50} \\
\hline & $\begin{array}{c}\text { To some } \\
\text { extent }\end{array}$ & 16 & 44.4 & \\
\hline & Very much & 20 & 55.6 & \\
\hline
\end{tabular}

burden "to some extent" while 17(47.2\%) were experiencing severe burden. The difference was not significant indicating that caregivers were equally likely to experience either moderate or severe burden. However, except for the spouse 
related and the caregiver strategy domains, the difference in the proportion of caregivers experiencing moderate and severe burden was found to be significant for the rest. The most severely affected areas were physical and mental health and taking responsibility where $25(69.4 \%)$ caregivers reported as suffering from severe burden. The least severely affected domain was external support where $6(16.7 \%)$ reported as suffering from severe burden. (Table 3)

Table no. 4: Distribution of the caregiver sample according to the coping strategy maximum used

\begin{tabular}{|c|c|c|c|}
\hline Coping strategy & Number & Percentage & $\begin{array}{c}\mathbf{P} \\
\text { value }\end{array}$ \\
\hline Active coping & 10 & 27.8 & \multirow{14}{*}{0.737} \\
\hline Planning & 13 & 36.1 & \\
\hline $\begin{array}{l}\text { Suppression of } \\
\text { competing } \\
\text { activities }\end{array}$ & 13 & 36.1 & \\
\hline Restraint coping & 11 & 30.6 & \\
\hline $\begin{array}{l}\text { Seeking social } \\
\text { support for } \\
\text { instrumental } \\
\text { reasons }\end{array}$ & 17 & 47.2 & \\
\hline $\begin{array}{c}\text { Seeking social } \\
\text { support for } \\
\text { emotional reasons }\end{array}$ & 16 & 44.4 & \\
\hline $\begin{array}{l}\text { Positive } \\
\text { interpretation and } \\
\text { growth }\end{array}$ & 9 & 25.0 & \\
\hline Acceptance & 11 & 30.6 & \\
\hline Turning to religion & 16 & 44.4 & \\
\hline $\begin{array}{c}\text { Focus on and } \\
\text { venting of } \\
\text { emotions }\end{array}$ & 11 & 30.6 & \\
\hline Denial & 0 & 0 & \\
\hline $\begin{array}{c}\text { Behavioural } \\
\text { disengagement }\end{array}$ & 5 & 13.9 & \\
\hline $\begin{array}{c}\text { Mental } \\
\text { disengagement }\end{array}$ & 1 & 2.8 & \\
\hline $\begin{array}{c}\text { Alcohol-drug } \\
\text { disengagement }\end{array}$ & 0 & 0 & \\
\hline
\end{tabular}

Assessment of coping strategies revealed that the most common coping strategy used by the caregivers at the time of admission was seeking social support for instrumental reasons with $17(47.2 \%)$ caregivers reporting maximum use of this strategy. This was followed by turning to religion and seeking social support for emotional reasons with $16(44.4 \%)$ caregivers reporting maximum use of both these strategies (Table 4). An overall analysis of only those strategies which have been clearly categorized as either problem oriented or emotion oriented in the COPE Inventory ${ }^{22}$ did not reveal any significant difference. This shows that the caregivers used both types of strategies equally. The mean scores were highest for turning to religion and seeking social support for instrumental reasons with 11.6 $\pm 3.2 \mathrm{SD}$ and 11.1 $\pm 4.2 \mathrm{SD}$ respectively. (Table 5 )

The small positive correlation between different subscales of PANSS and BAS was not found to be significant. Similarly, the choice of coping was also not found to be influenced by patients' symptoms. (Table 6)

Table no. 5: Mean Scores of COPE Inventory

\begin{tabular}{|c|c|c|}
\hline Coping strategy & Mean score & SD \\
\hline Active coping & 9.5 & 3.6 \\
\hline Planning & 10.2 & 4.4 \\
\hline $\begin{array}{c}\text { Suppression of competing } \\
\text { activities }\end{array}$ & 10.3 & 3.8 \\
\hline $\begin{array}{c}\text { Restraint coping } \\
\text { instrumental reasons }\end{array}$ & 9.9 & 4.3 \\
\hline $\begin{array}{c}\text { Seeking social support for } \\
\text { emotional reasons }\end{array}$ & 11.1 & 4.2 \\
\hline $\begin{array}{c}\text { Positive reinterpretation } \\
\text { and growth }\end{array}$ & 8.4 & 4.1 \\
\hline Acceptance & 10.1 & 4.3 \\
\hline Turning to religion & 11.6 & 3.2 \\
\hline $\begin{array}{c}\text { Focus on and venting of } \\
\text { emotions }\end{array}$ & 10.6 & 3.7 \\
\hline Denial & 4.9 & 1.9 \\
\hline Behavioural disengagement & 7.4 & 4.2 \\
\hline Mental disengagement & 6.9 & 2.5 \\
\hline $\begin{array}{c}\text { Alcohol-drug } \\
\text { disengagement }\end{array}$ & 1.1 & 0.5 \\
\hline
\end{tabular}

Table no. 5: Correlation between severity of symptoms, caregiver burden and coping strategies

\begin{tabular}{|c|c|c|c|c|}
\hline \multirow{2}{*}{ PANSS } & \multicolumn{2}{|c|}{ BAS } & \multicolumn{2}{c|}{$\begin{array}{c}\text { COPE } \\
\text { Inventory }\end{array}$} \\
\cline { 2 - 5 } & $\begin{array}{c}\mathbf{r} \\
\text { value }\end{array}$ & $\begin{array}{c}\mathbf{p} \\
\text { value }\end{array}$ & $\begin{array}{c}\mathbf{r} \\
\text { value }\end{array}$ & $\begin{array}{c}\mathbf{p} \\
\text { value }\end{array}$ \\
\hline \hline Total & 0.211 & 0.218 & 0.111 & 0.52 \\
\hline Positive subscale & 0.060 & 0.728 & 0.140 & 0.416 \\
\hline $\begin{array}{c}\text { Negative } \\
\text { subscale }\end{array}$ & 0.127 & 0.460 & -0.90 & 0.602 \\
\hline $\begin{array}{c}\text { General } \\
\text { psychopathology }\end{array}$ & 0.121 & 0.480 & 0.188 & 0.272 \\
\hline
\end{tabular}




\section{DISCUSSION:}

The fact that caregivers of patients with schizophrenia suffer from significant burden has been shown in several studies. ${ }^{6-11}$ This study shows that the caregivers in Nepal are no different with $47.2 \%$ reporting severe burden. The mean score of $81.3 \pm 15.9$ indicating severe burden is similar to the findings of Rammohan et al (2002) ${ }^{23}$. The major areas were physical and mental health, taking responsibility, patient's behavior and caregiver's routine. Feeling depressed and anxious and having financial difficulties have also been reported as the major area of burden in other studies. ${ }^{24}$ The finding that external support was the least affected domain is in contrast to the findings of Vasudeva et al (2013). ${ }^{25}$ The less severe burden in our study could be because of fewer female spouses in our study. As reported by Kumar and Mohanty (2007)26 female spouses of patients with schizophrenia often use projection as a defense mechanism which increases the interpersonal conflict resulting in greater difficulty in getting external support.

Whenever we encounter any event, through processes of primary and secondary appraisal we try to evaluate if the event is harmful and if it is, what can be done to prevent the harm. Accordingly we change our cognitive and behavior efforts. Caregivers in schizophrenia also use various strategies to overcome their distress. These strategies can be either adaptive or maladaptive. This study shows that they tend to use both problem oriented and emotion oriented strategies equally. Seeking social support has been shown to be an important strategy in other studies as well.10,11 Another important strategy in our study was turning to religion. This finding reflects the lower education level of the caregivers. As reported by Magliano et al (1998) caregivers with lower education level more frequently use seeking spiritual help as a coping strategy. ${ }^{27}$ The finding that caregivers used all strategies equally further emphasizes the need for proper psychoeducation of the caregivers.

A major limitation of our study is the limited sample size. As this study was done among caregivers of patients requiring admission, some may argue that it has overestimated the burden experienced by the caregivers. However, our study has failed to show any relation between the severity of symptoms and the burden experienced or choice of coping strategy. The relation between symptoms, burden and coping is not clear in literature. Further studies involving more number of patients from various settings are required to verify this finding.

\section{CONCLUSION:}

Caregivers are often the silent sufferers who not only have to deal with the patient's illness but the additional problems of their own. In view of these findings it is important to include them early in the treatment process and address their problems as well.

\section{ACKNOWLEDGEMENTS:}

The authors would like to thank all the patients and their caregivers who participated in the study and also the entire department of psychiatry, BPKIHS.

\section{REFERENCES:}

1. World Health Organization. Schizophrenia [Reviewed April 2016]. Available from http://www.who.int/mediacentre/factsheets/fs397/en/

2. Gater A et al. "Sometimes it's difficult to have a normal life": Results from a qualitative study exploring caregiver burden in schizophrenia. Schizophrenia Research And Treatment 2014 April 3;2014

3. Treudley MB. Mental illness and family routines. Mental Hygiene 1946;15:407-418

4. Hoenig $J$ and Hamilton MW. The schizophrenic patient in the community and it's effect on the household. International Journal of Social Psychiatry 1966;12:165-176

5. Provencher HL. Objective burden among primary caregivers of persons with chronic schizophrenia. Journal of Psychiatric and Mental Health Nursing 1996;3(3):181-187

6. Mandelbrote BM and Folkrad S. Some problems and needs of schizophrenics in relation to a developing psychiatry community service. Community Psychiatry 1961;2(6):317-328

7. Wing JK et al. Morbidity in the community of schizophrenic patients discharged from London mental hospitals in 1959. The British Journal of Psychiatry 1965;111:258-267

8. Stevens B. Dependence of schizophrenic patients on elderly relatives. Psychological Medicine 1972;2(1):17-32 
9. Schene et al. Family caregiving in schizophrenia: domains and distress. Schizophrenia Bulletin 1998;24(4):609-618

10. Magliano et al. Family burden and coping strategies in schizophrenia: are key relatives really different to other relatives? Acta Psychiatrica Scandinavica 2007;99(1):10-15

11. Tan et al. Burden and coping strategies experienced by caregivers of patients with schizophrenia in the community. Journal of Clinical Nursing 2012;21:2410-2418

12. Gerson et al. Self reported coping strategies in families of patients in early stages of psychotic disorder: an exploratory study. Early Intervention in Psychiatry 2011;5(1):76-80

13. Grandon et al. Primary caregivers of schizophrenia outpatients: Burden and predictor variables. Psychiatry Research 2008;158(3):335-343

14. Gibbons et al. Schizophrenic patients and their families. A survey in psychiatric service based on a DGH unit. The British Journal of Psychiatry 1984;144(1):70-77

15. Gopinath PS and Chaturvedi SK. Distressing behavior of schizophrenics at home. Acta Psychiatrica scandinavica 2007;86(3):185-188

16. Tennakoon et al. Experience of caregiving: relatives of people experiencing a first episode of psychosis. The British Journal of Psychiatry 2000;177(6):529-533

17. Birchwood M and Cochrane C. Families coping with schizophrenia: their origin and correlates. Psychological Medicine 1990;20:856-865

18. Deeken et al. Care for the caregivers: a review of the self report instruments used to measure burdens, needs and quality of life of informal caregivers. Journal of Pain and Symptom Management 2003;26(4):922-953

19. Rosenfarb et al. A sociocultural stress, appraisal and coping model of subjective burden and family attitudes toward patients with schizophrenia. Journal of Abnormal Psychology 2006;115(1):157-165

20. Kay et. The positive and negative syndrome scale for schizophrenia. Schizophrenia Bulletin 1987;13(2):261-276

21. Thara et al. Instrument to assess burden on caregivers of chronically mentally ill. Indian Journal of Psychiatry 1998;40(1):21-29

22. Carver et al. Assessing coping strategies: a theoretically based approach. Journal of Personality and Social Psychology 1989;56(2):267-283

23. Rammohan et al. Burden and coping in caregivers of persons with schizophrenia. Indian Journal of Psychiatry 2002;44(3):220-227

24. Talwar et al. Caregivers in schizophrenia: A cross cultural perspective. Indian Journal of Psychological Medicine 2010;32(1):29-33

25. Vasudeva et al. Caregivers burden of patients with schizophrenia and bipolar disorder: A sectional study. Indian Journal of Psychological Medicine 2013;35:352-357
26. Kumar S and Mohanty S. Spousal burden of care in schizophrenia. Journal of Indian Academy of Applied Psychology 2007;33(2):189-194

27. Magliano et al. Burden on the families of patients with schizophrenia: results of the BIOMED I study. Social Psychiatric Epidemiology 1998;33(9):405-412 